\author{
ANNALS OF “DUNAREA DE JOS” UNIVERSITY OF GALATI \\ MATHEMATICS, PHYSICS, THEORETICAL MECHANICS \\ FASCICLE II, YEAR X (XLI) 2018, No. 2
}

Article DOI: https://doi.org/10.35219/ann-ugal-math-phys-mec.2018.2.11

\title{
REVIEW ON WATER QUALITY ASSESSMENT IN THE DANUBE RIVER BASIN
}

\author{
Mădălina Călmuc ${ }^{*}$, Valentina Andreea Călmuc ${ }^{1}$, Maria Cătălina Ţopa ${ }^{1}$, \\ Mihaela Timofti ${ }^{1}$, Cătălina Iticescu ${ }^{1}$, Lucian P. Georgescu ${ }^{1}$, \\ 1 "Dunarea de Jos" University of Galati, European Center of Excellence for the Environment, Faculty of \\ Sciences and Environment, 111 Domneasca Street, 800201, Galati, Romania \\ *Corresponding author:calmucmadalina@yahoo.com
}

\begin{abstract}
The main goal of The Water Framework Directive 2000/60/EC is to define the state of all bodies of water in the terms of an ecological category according to the 5 classes of quality. Due to the fact that the Danube is the second longest river in Europe, the evaluation of its water quality has always been a very debated topic in domain specific studies. The water ecological status may be established by calculating various quality indices which embrace both physico-chemical parameters and biological ones. The aim of this paper is to synthesize the previous research studies on the assessment and monitoring of water quality in the Danube River basin. According to these studies, the quality of the Danube water was included in various classes throughout the entire stream. This was due to both the anthropogenic and natural influences on the Danube water quality.
\end{abstract}

Keywords: Danube River, water quality, ecological status, quality indices

\section{INTRODUCTION}

The Danube is the second longest river in Europe after the Volga, measuring 2,857 km and having a hydrographic basin which covers an area of about $805300 \mathrm{~km}^{2}$. From its spring to its emptying into the Black Sea, the Danube flows through ten countries (Germany, Austria, Slovakia, Hungary, Croatia, Serbia, Romania, Bulgaria, Moldova, Ukraine) and four capitals (Vienna, Bratislava, Budapest and Belgrade) [1-2]. The Danube represents a very important natural resource for all these countries, being a source of water, electricity and fish, as well as a navigation route used for economic and recreational activities. Crossing so many countries, the Danube River also represents the main collector of urban and industrial wastewater, such activities having a significant impact on its water quality. For this reason, special attention should be paid to the assessment of the Danube water quality [3-7].

At the end of the year 2000, the European Union adopted the Water Framework Directive (Directive 2000/60/EC), representing the main tool for water quality assessment. Its main goal is to ensure a "good" quality status for all the surface and underground bodies of water in order to cope with the actual and potential needs of water. All EU states had to implement their own monitoring programs until 2015 in order to meet this goal, and to further apply the necessary measures to diminish the factors which influence water quality. According to the Water Framework Directive, the ecological status of a surface water may be established by monitoring its physico-chemical and biological parameters, as well as its particles suspension and sediments. The biological component includes parameters as: phytoplankton, macrophytes, phytobenthos, zoobenthos and ichthyofauna [8-11]. 
The aim of this paper is to synthesize previous researches on the water quality assessment and monitoring in the Danube River basin, especially due to the fact that approximately $30 \%$ of the Danube basin is situated on the Romanian territory. Once the actual state of the relevant studies on the Danube is known, the implementation of new research directions at local and regional levels may be defined.

\section{RESARCH ON WATER QUALITY ASSESSMENT IN THE DANUBE RIVER BASIN}

\subsection{Monitoring the physico-chemical parameters}

The selection of the monitoring parameters is made according to the purpose for which the water is used. The assessment of the physico-chemical water quality implies analysing various physico-chemical parameters such as: temperature, colour, smell, taste, total of dissolved salts (TDS), $\mathrm{pH}$, turbidity, conductivity, nutrients (ammonium, nitrites, nitrates, phosphates, total phosphorus, total nitrogen). the oxygen regime (dissolved oxygen, chemical and biochemical oxygen demand, ), total organic carbon, alkalinity, acidity, hardness, minerals $\left(\mathrm{Ca}^{2+,} \mathrm{Mg}^{2+} \mathrm{K}^{+}, \mathrm{Na}^{+}, \mathrm{SO}_{4}{ }^{2}-\mathrm{Cl}^{-}\right.$etc. $)$, metals, especially heavy metals ( $\mathrm{Fe}, \mathrm{Pb}, \mathrm{Cd}, \mathrm{Hg}, \mathrm{Mn}, \mathrm{As}, \mathrm{Zn}, \mathrm{Cr}, \mathrm{Ni}$ etc.) and organic and inorganic micro pollutants (phenols, AOX, detergents, petroleum hydrocarbons etc.) [12].

As far as the level of nutrient sources (phosphorus and nitrogen) is concerned, a decrease was recorded in Germany, Moldova and Ukraine between 1998-2000 and a significant increase in Croatia, Serbia, Slovakia and Montenegro in the same interval of time. The nature of nutrient sources varies from country to country. For instance, the urban settlements in Hungary, Serbia and Montenegro represent the main factor conditioning the azote levels, whereas in other countries these levels are influenced by the atmospheric deposition of NOx (Austria and Bosnia-Herzegovina) or by agricultural activities. As regards the phosphorus levels, they are mainly influenced by agriculture in most riparian countries, except for Germany and Austria [13].

Woitke et al. (2003) studied the contents of heavy metals dissolved in sediments and suspended solids from 74 stations along the Danube course, from Neu-Ulm $(2589 \mathrm{~km})$ to the Danube flowing into the Black Sea $(0 \mathrm{~km})$. The monitoring was carried out in 2001 and the results of heavy metals concentration ( $\mathrm{As}, \mathrm{Cd}, \mathrm{Cr}, \mathrm{Cu}, \mathrm{Fe}, \mathrm{Pb}, \mathrm{Mn}, \mathrm{Hg}, \mathrm{Ni}, \mathrm{Zn}$ ) were obtained from the Joint Danube Survey 1(JDS1). The results indicated low concentrations on the territory of Hungary $(1500 \mathrm{~km})$, an increase down the river $(1000 \mathrm{~km})$ and a slight decrease down to and in the Danube Delta. However, the concentrations obtained are considered to be low, except for cadmium $(\mathrm{Cd})$, which was found in high concentrations in the Lower-Danube, starting from the Iron Gates (Romania) [1].

A convenient method to establish the ecological status of a surface water is to calculate the quality indices which include a variable number of physico-chemical and biological parameters. The most used indices to assess the Danube water quality are: the Water Quality Index-WQI [14], the Water Pollution Index-WPI [15-16] and the Heavy Metal Pollution Index-HPI [17].

The efficiency of the Water Quality Index has been confirmed on the Lower-Danube sector in Romania as a result of the seasonal and annual monitoring. During the summer of the 2012, the values of the WQI were between 41,07-55,39, corresponding to "good ecological status". The highest values were recorded during autumn, while the lowest during winter. This is due to the variations in the river flow, which is lower during summer and higher during winter [14].

The Water Pollution Index was calculated in Serbia, the values registered in 2014 being between 1,12-1,54, with an average value of 1,352 . These values correspond to those of a moderately polluted water. Total organic carbon, phosphates and total phosphorus were the most important parameters which influenced the water quality and which exceeded the standard values [16].

A study evaluating the pollution with heavy metals, using as tool the Heavy Metal Pollution Index - HPI was made on the Calarasi-Braila sector $(375-175 \mathrm{~km})$, from September 2011 to August 2013. All the values obtained were below the threshold value (100), the lowest values reaching 24,91 and highest 32.29 [17]. 


\subsection{Monitoring the Biological Parameters}

Each riparian country uses specific methods to evaluate the water quality in the Danube basin from a biological point of view. Germany monitors macrozoobenthos and the periphyton to establish the organic load. Furthermore, the phytobenthos and the macrophytes are also monitored for evaluating the ecological state of water. The Saprobic Index and the Potamon Typie Index are among the most used biological indicators. In Austria, different biological parameters are observed based on the analysis of different species of vegetation and fauna with bioindicator values. Two methods were implemented at the end of 2004 in order to align with the Water Framework Directive requirements: one implying the monitoring of ichthyofaunal, and the other implying the creation of multimetric index based on analysing the macrozoobenthos. Germany and the Czech Republic use two important evaluation systems for water quality based on the indicators: AQEM and PERLA. Slovakia, Hungary, Croatia, Romania, Ukraine and Moldova use Saprobic Index. Moreover, Romania and Hungary use an adapted form of the BMWP Score System, as well as Saprobe Index calculated according to the Pantle Buck method, while Moldova and Ukraine calculate the ratio of oligochaetes. Bulgaria mainly uses its own method the Irish "Quality Rating System", consisting in the monitoring of the relative abundance of five classes of benthic macroinvertebrates which present different tolerances to organic pollution [18].

\section{- Macrozoobenthos}

The distribution and the abundance of macrozoobenthos provide important information about the content of organic matter, sediments, the substrate type and especially about the water quality [1920].

In 2000, the water quality in the Danube sector below Vienna was evaluated by calculating six biological indices of quality. Zelinka \& Marvan Saprobic Index registered values between 1,68 - 2.06 (temporal variation) and 1,75-2,11 (spatial variation), the quality conditions being $\beta$-mesosaprobic. Pantle-Buck Index indicated a quality of water situated in the second class, while the Trent Biotic Index, the Extended Biotic Index and the Biotique Index indicate a water quality class between I and II for the temporal monitoring, and between I and II-III for the spatial one. The values for the Makroindex varied between 5 and 6 , where 1 indicates the highest quality and 8 the lowest one. According the BMWP and Lincoln indices, the water was classified in the classes I-III [21].

According to the Joint Danube Survey 2, the values of the Saprobic Index varied from 1,83 to 3,15 for the monitored stations in 2007. 9 sites were classified as having high ecological status, 58 had a good ecological status, 8 sites had moderate and 3 sites poor ecological status [22].

Graf et al. (2015) studied the ecological status of the Danube by monitoring the diversity of the benthic macroinvertebrates in 55 sites along the Danube basin. The Saprobic Indexes for the 55 selected sites varied between 1,88 and 3,32. According to the values obtained for the Saprobic Index, $73 \%$ (40 sites) had good ecological status, 5\% (9 sites) had moderate and 4\% (2 sites) high ecological status [23].

\section{- Phytoplankton and Macrophytes}

The phytoplankton is an important source of valuable information about the trophic status of the aquatic ecosystem, as well as about the concentration of nutrients and of other pollutants. According Dokulil and Donabaum (2014), diatoms (Bacillariophyceae) and green algae (Chlorophyta) are the dominant components of phytoplankton in the Danube River [24].

The concentration of chlorophyll $\mathrm{a}$ is analysed for the evaluation of the phytoplankton. According to the Joint Danube Survey 3, the concentration of chlorophyll between Klosterneuburg ( $\mathrm{km} \mathrm{1942)} \mathrm{and} \mathrm{Budapest} \mathrm{(km} \mathrm{1660)} \mathrm{exceeded} \mathrm{the} \mathrm{limit} \mathrm{values} \mathrm{in} \mathrm{2013.} \mathrm{This} \mathrm{was} \mathrm{due} \mathrm{to} \mathrm{the} \mathrm{high}$ temperatures registered throughout the monitoring period. The water from most of the monitoring stations corresponded to quality class I, the water in three stations belonged to quality class II and in only two stations to quality class III [25]. 
The distribution of macrophytes along a river depends on the physico-chemical properties of the water, substrate, flow velocity, climatic conditions and also on the anthropic influence [26]. The macrophytes are used as indicators of water quality due to their allowing localisation of the pollution point source and to their longevity [27].

Macrophytes belonging to the same class (Monocotyledoneae) but to different families (Cyperacee, Butmoaceae, Potamogetonaceae) were identified on the Calarasi-Braila Danube sector, in June 2011. However, the number of macrophytes registered was reduced, no species of macrophytes being identified in 3 out of the 8 monitoring stations. This is mostly due to the water currents but also to the Danube water level variation that year [28]. 49 species of aquatic vascular plants were registered on the territory of Serbia (sector 14330-846 km) during July of 2012-2013 the most frequently encountered being Ceratophullum demersum, Potamogeton pectinauturs and Butomus umbellatus [29].

\section{- Ichthyofauna}

The fish are monitored for the evaluation of the ecological state of an aquatic ecosystem because they seem to present varied adaptability to abiotic conditions [30]. According to the study realised by Schiemer et al.(2004), there are approximately 100 species of fish in the Danube. The highest diversity is encountered in the transition sector between the foothills and lowlands in Austria, and in Romania due to the migration of new species of fish from the Black Sea. In the last century, 15 new exotic species such as: Carassius gihelio, Pseudorasbora parva, Lepomis gibbosus, Ctenopharyngodon idella, Aristichthys nobilis etc. have been introduced [31].

In order to highlight the possible existence of a relation between the decrease in the number of fish specimens and the water quality in the upper Danube, fish from Barbus barbus L. species were captured from three sampling stations with different ecological states. Following the analyses made on the tissue of fish originating from the polluted stations, some dysfunctions at the ultrastructural level, of the hepatic cells were identified. Consequently, the degradation in the health of the fish due to the pollutant conditions may represent a cause of the decrease in fish population throughout the analysed sector [32].

During the last century, the number of sturgeons in the Danube has considerably decreased, this species being currently on the verge of extinction. For this reason, the six sturgeon species present now in the Danube are protected by law, and special attention is paid to the conservation and breeding of this fish. According to current studies, the Acipenser sturio and Acipenser nudiventris species are considered to be extinct from the Danube, whereas the Acipenser ruthenus species is endangered on the inferior and middle Danube and almost extinct on the superior one. The main cause of the decrease in the populations of sturgeons is mostly the excessive poaching, usually practised for black caviar [33].

\section{CONCLUSIONS}

The physico-chemical and biological parameters must be monitored in order to establish the water quality. The most efficiently used method is the calculation of some quality indices which include a variable number of physico-chemical parameters, as well as of biological ones. However, a global water quality assessment method that could be used worldwide has not been established yet.

The advantage of calculation a series fof water quality indices such as WQI, WPI, HPI etc. is represented by the fact that the value obtained reflects the weight that each monitored parametre has on the general ecological status. The monitoring of such complex aquatic ecosystems, as the Danube River, requires calculating several quality indices. This is mostly mandatory when evaluating a larger number of parameters because each index includes an individual number of indicators.

The evaluation of biological parameters is essential because these parameters quantify the effects of long-term pollution due to their sensitivity to pollutants. The most used biological index in 
monitoring the quality of the Danube is the Saprobic Index. This index may be used in monitoring the phytoplankton, as well as the macrozoonbenthos.

From the analysis and synthesis of the studies on the water quality assessment in the Danube River basin, the conclusion may be drawn that the Danube water may not be classified into one quality class throughout its course. This is due to the different sources of pollution which represent a major influence on the river water quality, but also to the natural processes specific to each area.

Acknowledgement: This work was supported by the project "Strategy and actions for preparing the national participation in the DANUBIUS-RI Project" acronym "DANS" financed by the Romanian Ministry of Research and Innovation.

\section{References}

1. Woitke P., Wellmitz J., Helm D., Kube P., Lepom P., Litheraty P., Analysis and assessment of heavy metal pollution in suspended solids and sediments of the river Danube, Chemosphere, 51, 633-642, 2003.

2. Kolarević S., Knežević-Vukčević J., Paunović M., Tomović J., Gačić Z., Vuković-Gačić B., The anthropogenic impact on water quality of the River Danube in Serbia: Microbiological analysis and genotoxicity monitoring, Arch. Biol. Sci., 63(4), 1209-1217, 2011.

3. Simeonov V., Sarbu C., Massart D. L., Tsakovsk S., Danube River Water Data Modelling by Multivariate Data Analysis, Mikrochim. Acta, 137, 243-248, 2001.

4. Enache I., Birghila S., Dumbrava A., The Danube River water quality characteristics in the Braila Town, Ovidius University Annals of Chemistry, 20(2),146-152, 2009.

5. Voza D., Vukovic M., Takic L., Nikolic D., Mladenovic-Ranisavljevic I., Application of multivariate statistical techniques in the water quality assessment of Danube river, Serbia, Arch Environ Prot., 41(4), 96-103, 2015.

6. Ilie M., Marinescu F., Szep R.., Ghița G., Deak G., Anghel A. M., Petrescu A., Urițescu B., Ecological risk assessment of heavy metals in surface sediments from the Danube River, Carpath. J. Earth Environ. Sci., 12(2), 437 - 445, 2017.

7. Sharma V., Walia Y. K., Kumar A., Assessment of Physico Chemical Parameters for Analysing Water: A Review, J. Biol. Chem. Chron., 2, 25-33, 2015.

8. Filipova M., Zheleva I., Roussev P., Investigation of monitoring systems for water quality of the Danube River in the border region Romania - Bulgaria, INCD ECOIND - International Symposium - SIMI 2013 "The environment and the industry", 2013.

9. Vrana B., Klucárová V., Benická E., Abou-Mrad N., Amdany R., Horáková S., Draxler A., Humer F., Gans O., Passive sampling: An effective method for monitoring seasonal and spatial variability of dissolved hydrophobic organic contaminants and metals in the Danube river, Environ Pollut., 184, 101-112, 2014.

10. Ibănescu D. C., Popescu A., Nica A., Assessment of water quality in the Danube river (Călăraşi Brăila Section, km 375 - km 175), Current Trends in Natural Sciences, 6(11), 202208, 2017.

11. Directive 2000/60/EC of the European Parliament and of the Council of 23 October 2000 establishing a framework for Community action in the field of water policy.

12. Patil P. N, Sawant, D. V, Deshmukh, R. N., Physico-chemical parameters for testing of water - A review, International Journal of Environmental Sciences, 3(3), 1194-1207, 2012.

13. Gasparotti C., The main factors of water pollution in Danube River basin, EuroEconomica, 1(33), 91-106, 2014.

14. Iticescu C., Georgescu L.P., T,opa, C.M., Assessing the Danube water quality index in the city of Galati, Romania, Carpath. J. Earth Environ. Sci., 8(4), 155-157, 2013. 
15. Milanović A., Milijašević D., Brankov J., Assessment of polluting effects and surface water Quality using Water Pollution Index: A case study of Hydro - system Danube - Tisa Danube, Serbia, Carpath. J. Earth Environ. Sci, 6(2), 269 - 277, 2011.

16. Takić L., Mladenović-Ranisavljević I., Vasović D., Đorđević, L., The Assessment of the Danube River Water Pollution in Serbia, Water, air, and soil pollution, 228(10), 228-380, 2017.

17. Ionescu P., Radu V. M., György D., Ivanov A. A., Diacu E., Lower Danube Water Quality Assessment Using Heavy Metals Indexes, Revista de Chimie (București), 66(8), 1088-1092, 2015.

18. Birk S., Schmedtje U., Towards harmonisation of water quality classification in the Danube River Basin: Overview of biological assessment methods for running waters, Arch.Hydrobiol. Suppl, 158, 171-196, 2005.

19. Arslan N., Ilhan S., Sahin Y., Filik C., Yilmaz V., Onturk T., Diversity of invertebrate fauna in littoral of shallow Musaozu dam lake in comparison with environmental parameters, Journal of Applied Bioscience, 1, 67-75, 2007.

20. Trichkova T, Tyufekchieva V., Kenderov L.,Vidinova Y., Botev I., Kozuharov D., Hubenov Z., Uzunov Y., Stoichev S., Cheshmedjiev S., Benthic Macroinvertebrate Diversity in Relation to Environmental Parameters, and Ecological Potential of Reservoirs, Danube River Basin, North-West Bulgaria, Acta zool. bulg., 65(3), 337-348, 2013.

21. Humpesch U, Fesl C., Biodiversity of macrozoobenthos in a large river, Austrian Danube, including quantitative studies in a free-flowing stretch below Vienna:A short review, Freshwater Forum, 24, 3-23, 2005.

22. Graf W., Csányi B., Leitner P, Paunovic M., Chiriac G., Stubauer I., Macroinvertebrates, in Joint Danube Survey 2, (Liška I., Wagner F., Slobodník J., editors), ICPDR - International Commission for the Protection of the Danube River 2008, Vienne, Austria, 42-50.

23. Graf W., Csányi B., Leitner P., Paunović M., Huber T., Szekeres J., Nagy C., Borza P., Macroinvertebrates, in Joint Danube Survey 3, (Liška I., Wagner F., Slobodník, J, editors), ICPDR - International Commission for the Protection of the Danube River 2015, Vienne, Austria, 81-87.

24. Dokulil M., Donabaum U., Phytoplankton of the Danube River: Composition and Long-Term Dynamics, Acta zool. bulg., 7, 147-152, 2014.

25. Dokulil M, Donabaum, U., Phytoplankton, in Joint Danube Survey 3, ( Liška I., Wagner F., Sengl M., Deutsch K., Slobodník J., editors), ICPDR - International Commission for the Protection of the Danube River 2015, Vienne, Austria, 19-125.

26. Fabris M., Schneider S., Melzerc A., Macrophyte-based bioindication in rivers - A comparative evaluation of the reference index (RI) and the trophic index of macrophytes (TIM), Limnologica, 39(1), 40-55, 2009.

27. Pall K., Mayerhofer V., 2015, Guidance on the monitoring of the biological quality elements part A4 - Macrophytes, Viena-Austria, 7-8.

28. Vasilean I., Vasilean I., Ibănescu D. C., 2015, The distribution of aquatic macrophytes on Danube River beetween Calarasi and Braila, Bulletin UASVM Agriculture, 72, 1, 317-318.

29. Vukov D., Ilić M., Ćuk M., Igić R., Janauer G. A., 2017, The relationship between habitat factors and aquatic macrophyte assemblages in the Danube River in Serbia, Arch Biol Sci., 69, $3,427-437$.

30. Schiemer F., Guti G., Keckeis H., Staras M., 2004, Ecological status and problems of the Danube River and its fish fauna: A review, Proceedings of the second international Symposium on the management of large rivers for fisheries, 273-300.

31. Schiemer F., Fish as indicators for the assessment of the ecological integrity of large rivers, Hydrobiologia, 422/423, 271-278, 2000.

32. Grund S., Keiter S., Böttcher M., Seitz N., Wurm K., Manz W., Hollert H., Braunbeck T., Assessment of fish health status in the Upper Danube River by investigation of ultrastructural alterations in the liver of barbel Barbus barbus, Diseases of aquatic organisms, 88, 235-248, 2010. 
33. ICPDR, 2018, Sturgeon Strategy, 1-20. 